\title{
DATING OF THE CULTURAL LAYERS FROM VILNIUS LOWER CASTLE, EAST LITHUANIA: IMPLICATIONS FOR CHRONOLOGICAL ATTRIBUTION AND ENVIRONMENTAL HISTORY
}

\author{
$\mathrm{J}_{\text {Mažeika }}^{1,2}$ • P Blaževičius ${ }^{3}$ • M Stančikaitė ${ }^{1}$ D Kisielienè ${ }^{1}$
}

\begin{abstract}
Complex interdisciplinary studies carried out in the territory of the Vilnius Lower Castle, E Lithuania, were used to construct a chronological framework based on radiocarbon data and archaeological information. Bulk samples (wood and sediment) were collected from an approximately 3-m core that crossed cultural layers and underlying strata. ${ }^{14} \mathrm{C}$ dates indicate that the underlying bed possibly formed during the 6th century $\mathrm{AD}$, although no archaeological finds were discovered there. Paleobotanical (pollen and plant macrofossil) investigations reveal evidence of agriculture that points to the existence of a permanent settlement in the area at that time. The chronological data indicates a sedimentation hiatus before the onset of the deposition of the cultural layer in the studied area. The ${ }^{14} \mathrm{C}$ dates showed that the formation of the cultural bed began during the late 13th-early 14th centuries $\mathrm{AD}$, that is, earlier than expected according to the archaeological record. The ongoing deposition of the cultural beds continued throughout the middle to latter half of the 14th century AD as revealed by the archaeological records and confirmed by well-correlated ${ }^{14} \mathrm{C}$ results. After some decline in human activity in the middle of the 14th century $\mathrm{AD}$, a subsequent ongoing development of the open landscape, along with intensive agriculture, points to an increase in human activity during the second half of the 14th century AD. The first half of the 15th century AD was marked by intensive exploitation of the territory, indicating a period of economic and cultural prosperity. The chronological framework indicates that the investigated cultural beds continued forming until the first half of the 16th century AD.
\end{abstract}

\section{INTRODUCTION}

Reconstructing a population history requires an accurate chronology, which is often difficult to establish for a variety of natural and anthropogenic reasons. Yet because chronological investigations of cultural content are characterized by several specific features in regards to available material, the sedimentation environment, sampling strategies, etc., this difficulty can be overcome through multidisciplinary investigations. Radiocarbon dating provides a reliable background for the development of an independent chronological framework for determining the age of the cultural record. Such investigations have been conducted on archaeological and historical monuments around the eastern Baltic and have provided scientists with new information on the population history of this part of Europe (Butrimas 1992; Pazdur et al. 1994; Rimantiené 2005; Veski et al. 2005; Zagorska 2006; Pukienè 2007).

Recent multidisciplinary investigations of this type have been carried out in the territory of the Vilnius Lower Castle in eastern Lithuania. The studies integrate the results of ${ }^{14} \mathrm{C}$ dating and paleobotanical (pollen and plant macrofossil) analysis with archaeological evidence. Due to the fact that detailed archaeological excavations have been ongoing in the area for several decades, there is quite a rich collection of archaeological material confirming the existence of a permanent settlement at the site during the 5th-8th centuries AD (Kitkauskas 1989; Tautavičius and Urbanavičius 1995; Urbanavičius 2003). Supporting this evidence are a dendrochronological survey and the ${ }^{14} \mathrm{C}$ dating of particular finds or sediments layers (Gaigalas et al. 1999; Pukiené 2007; Pukienė and Ožalas 2007). However, prior to this study no systematic ${ }^{14} \mathrm{C}$ studies indicating the age of the cultural layers had been performed at this site.

\footnotetext{
${ }^{1}$ Institute of Geology and Geography, T. Ševčenkos Str. 13, LT-03223 Vilnius, Lithuania.

${ }^{2}$ Corresponding author. Email: mazeika@geo.lt.

${ }^{3}$ Institute of History and Archaeology of the Baltic Sea Region, University of Klaipėda, Tilžès Str. 13, LT-91251 Klaipèda, Lithuania.
}

(C) 2009 by the Arizona Board of Regents on behalf of the University of Arizona

Proceedings of the 5th International ${ }^{14} \mathrm{C}$ and Archaeology Symposium, edited by Irka Hajdas et al.

RADIOCARBON, Vol 51, Nr 2, 2009, p 515-528 


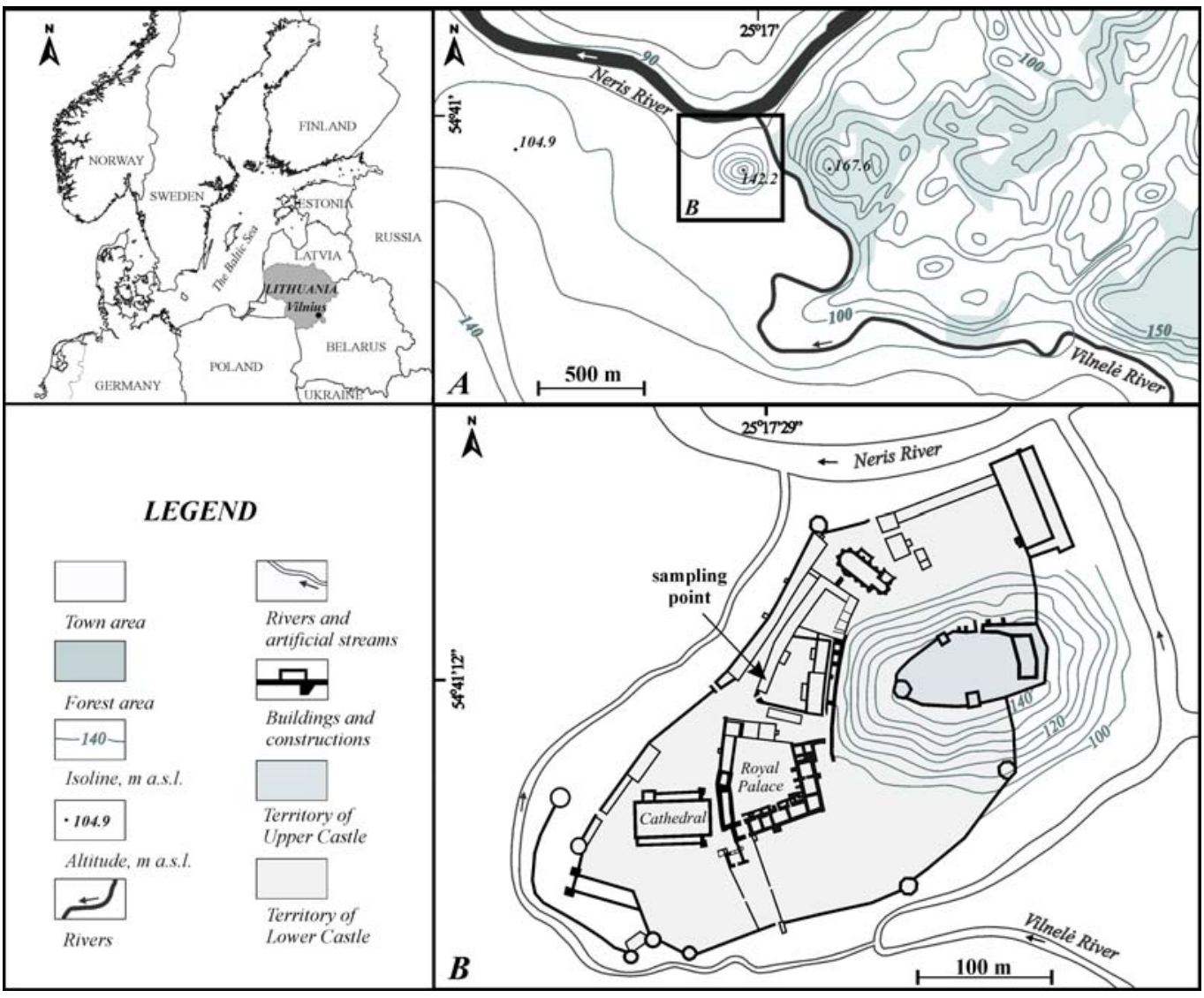

Figure 1 Location of the Vilnius Royal Castle (A) and position of sampling points (B)

As such, the main aim of this study is to indicate the chronological attribution of the cultural layers in the recently investigated part of the Vilnius Lower Castle and to discuss this new data in the context of the population history recorded at this particular historical monument (Kitkauskas 1989; Tautavičius and Urbanavičius 1995; Urbanavičius 2003) and described in historical sources (Bumblauskas 2005; Kuncevičius 2005). To accomplish this, a series of ${ }^{14} \mathrm{C}$ data, along with archaeological information retrieved from one of the archaeological trenches, has been collected and analyzed. While a rich set of archaeobotanical material was collected and investigated simultaneously, in this paper only a brief overview of the environmental history and indicated human activity is presented; this data is discussed in greater detail in a separate manuscript (Stančikaite et al. 2008).

The Vilnius Castles were located in the center of present-day Vilnius, at the confluence of the Neris and Vilnelè rivers (Figure 1). Formed during the retreat of the Late Weichselian ice sheet (Guobytè 2002), the landscape of this area is one of the most picturesque in eastern Lithuania. The prominent hills of erosion origin that appear eastwards from the Vilnele River transform westwards into flat, sandy terraces of alluvial origin (Figure 1A). Constructed on this landscape, the Vilnius Castles complex consisted of an Upper Castle that was situated on a top of an erosion hill ( $140 \mathrm{~m}$ asl) and a Lower Castle (91.6 m asl) that stretched at the foot of it (Figure 1B). An archaeological trench with sampling columns $\left(54^{\circ} 41^{\prime} 12^{\prime \prime} \mathrm{N}, 25^{\circ} 17^{\prime} 29^{\prime \prime} \mathrm{E}\right)$ was situated in the area of the courtier palace, which existed in the inner yard of the Lower Castle in the 16th-18th centuries AD (Figure 1B). 


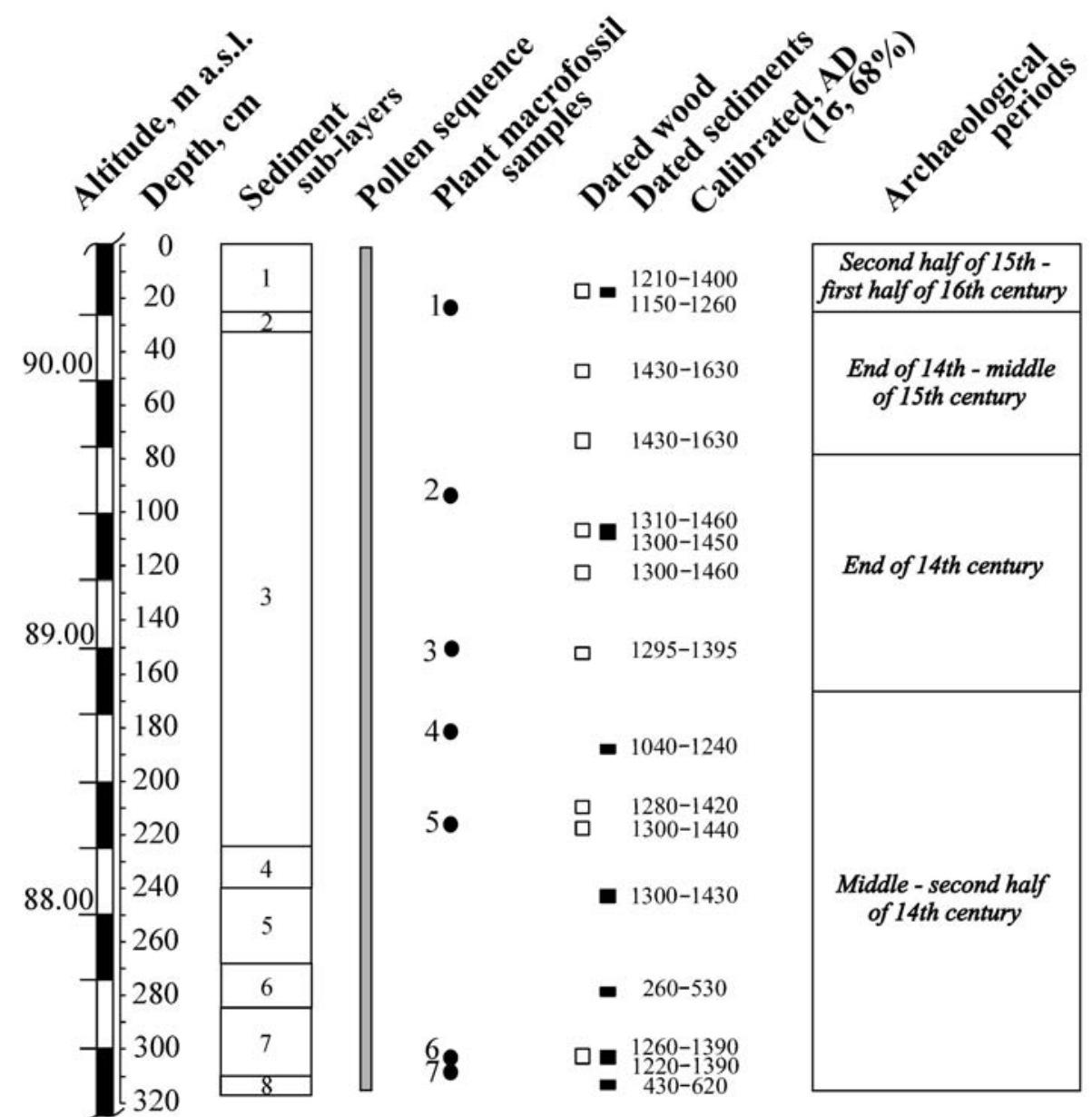

Figure 2 Schematic view indicating investigated sediment sublayers, pollen sequence, plant macrofossil samples, ${ }^{14} \mathrm{C}$ samples and chronological subdivision of the cultural layers based on archaeological data.

\section{MATERIAL AND METHODS}

Detailed archaeological excavations in the territory of the Vilnius Lower Castle (Figure 1) began in the 1990s, and in 2003-2006 the territory of the courtier palace was excavated. A cultural layer reaching up to $7 \mathrm{~m}$ in depth was investigated using the standard methodology. Within the investigated plot $(24.5 \times 11 \mathrm{~m})$, the remains of buildings, pavements, fens, and pits were discovered. While the primary function of the numerous buildings is still uncertain, it is possible that they could have served as dwellings or storage facilities. The presence of numerous pavements indicates that multiple reconstructions occurred in the area. In addition, the cultural layer was enriched by numerous remains of burnt wood and clay, discarded potsherds, and various archaeological artifacts, including coins and jewelry from different epochs of the 2nd millennium AD. A high content of organic material in the cultural layer was also visually recorded.

For the ${ }^{14} \mathrm{C}$ dating and paleobotanical investigations (plant macrofossil and pollen survey), multiple sediment sequences (up to $315 \mathrm{~cm}$ in depth) (Figure 2) were taken from a wall of the archaeological trench. The first core was subsampled at 2-cm intervals. Most samples were used for pollen analysis, although 4 small samples from this core were dated by ${ }^{14} \mathrm{C}$. For the plant macrofossil survey and 
additional ${ }^{14} \mathrm{C}$ dating (every $5 \mathrm{~cm}$ ), 2 parallel cores were subsampled. In all, 16 samples, including wood pieces and sediment more or less evenly spaced along the sediment sequence, were dated.

In the laboratory, the samples were additionally dried and visually examined, and rootlet contaminants were collected. Any surface contamination from single wood pieces was removed before chemical pretreatment. All samples were then crushed and treated by acid-alkali-acid (AAA) washing to remove contamination by carbonates and humic acids, after which the ${ }^{14} \mathrm{C}$ dates on selected larger wood pieces and sediment were produced. The specific activity of ${ }^{14} \mathrm{C}$ in benzene produced from samples was measured by the liquid scintillation counting method as described in Gupta and Polach (1985), Arslanov (1985), and Bowman (1995). The technological line for benzene synthesis and purification used in this study is described by Kovaliukh and Skripkin (1994). Samples that contained high levels of organic carbon and that were chemically pretreated were burned in pyrolysis to get charred material. During this process, depending on the origin of sample material, some significant datable carbon fraction escaped with the pyrolysis gases. As a result, the benzene output from the samples was different, resulting in dates with variable uncertainties. The following main procedures for benzene synthesis were followed: (1) reaction of carbon-containing sample material with $\mathrm{Li}$ in the metallic reactor at temperature $550-600{ }^{\circ} \mathrm{C}$ receiving $\mathrm{Li}_{2} \mathrm{C}_{2}$; (2) hydrolysis of $\mathrm{Li}_{2} \mathrm{C}_{2}$, receiving $\mathrm{C}_{2} \mathrm{H}_{2}$; (3) synthesis of benzene by cyclotrimerization of $\mathrm{C}_{2} \mathrm{H}_{2}$ using a catalyst containing aluminous-silicate and activated with $\mathrm{V}_{2} \mathrm{O}_{5}$; (4) purification of benzene by adding metallic sodium and distillation; and (5) adding the scintillation admixtures, PPO (2,5-dipheniloxazole) and POPOP (1,4-bis(5-phenyl-2-oxazolyl)benzene), to the benzene sample. The ${ }^{14} \mathrm{C}$ specific activity of benzene was determined by the use of the liquid scintillation analyzer Tri-Carb 3170TR/SL in the Radioisotope Research Laboratory, Institute of Geology and Geography, Vilnius. The main performance parameters of the analyzer for ${ }^{14} \mathrm{C}$ in benzene form with full 3-mL copper Teflon ${ }^{\circledR}$ vials were as follows: a background count rate of $0.41 \pm 0.04 \mathrm{CPM}$; a counting efficiency of $71.3 \pm 0.8 \%$; and a figure of merit (efficiency ${ }^{2}$ /background) of $12,380 \pm 700$. The ${ }^{14} \mathrm{C}$ calibration program OxCal v 3.10 (Bronk Ramsey 1995, 2001) with the IntCal04 data set (Reimer et al. 2004) was used for the calibration of ${ }^{14} \mathrm{C}$ dates. All dates are given at the $1-\sigma$ confidence level and expressed in calendar yr AD.

Subsamples of $3 \mathrm{~cm}^{3}$ for pollen analysis were prepared using a standard chemical procedure (Erdtman 1936; Grichiuk 1940), including treating the sediments with a heavy liquid (CdI $+\mathrm{KI}$. More than 500 terrestrial pollen grains were counted from each sample and identified using Moore et al. (1991). Taxa are presented as percentages of the sum of arboreal ( $\Sigma A P)$ plus non-arboreal ( NAP) taxa. The percentage diagram was plotted using the programs TILIA and TILIA-GRAPH (Grimm 1992).

Plant macrofossils were extracted from sediment samples ( $800 \mathrm{~cm}^{3}$ in volume) by wet sieving on 2 screens with mesh sizes of 0.2 and $0.5 \mathrm{~mm}$. Discovered macrofossils were sorted using $16 \times$ magnification. The identification of macrofossils was made by comparison with modern specimens from the reference collections of the University of Gdańsk, Institute of Geology and Geography, Vilnius, and the identification atlases of Grigas (1986), Jacquat (1988), and Latałowa (1999). Botanical nomenclature follows Gudzinskas (1999). Identified taxa have been arranged in broadly defined ecosociological groups (Latałowa et al. 2003; Behre and Jacomet 1991).

\section{RESULTS}

\section{Sediment Composition}

The investigated sediment sequences (Figure 2) consist of 8 major, visually distinguishable sublayers (Table 1). A sublayer of gray sand with an admixture of organogenic material was present in the 
bottom of the core (sublayer 8, Table 1). This sublayer does not contain archaeological finds. The rest of the core comprising the cultural strata but of a different color was subdivided into 7 sublayers (sublayers 1-7, Table 1).

Table 1 Brief description of the sediment sequence.

\begin{tabular}{|c|c|c|}
\hline Depth (cm) & Sublayer & Main features of sediment sequence \\
\hline $0-25$ & 1 & Black cultural layer \\
\hline $25-32$ & 2 & Grayish cultural layer with sand lenses \\
\hline $32-25$ & 3 & $\begin{array}{l}\text { Dark brown cultural layer with abundant wood remains }(172-180 \mathrm{~cm} \\
\text { interlayer of ash with greenish sand) }\end{array}$ \\
\hline $225-240$ & 4 & Brownish cultural layer with wood remains and admixture of greenish sand \\
\hline 240-269 & 5 & Dark brown cultural layer \\
\hline 269-285 & 6 & Dark brown cultural layer with wood \\
\hline $285-310$ & 7 & Dark gray cultural layer with ash, charred particles and charcoals \\
\hline $310-315$ & 8 & Grayish various-grained sand with organogenic material \\
\hline
\end{tabular}

\section{Archaeological Data}

An archaeological survey carried out in the lower part of the cultural bed, laying at $87.20-88.95 \mathrm{~m}$ asl (sublayers 3-7), revealed the presence of numerous pieces of treated wood. Their purpose, though, is undetermined, nor were specific constructions identified. Instead, this part of the cultural layer was dated on the basis of the archaeological findings, which include a tin ring with a hexagonal head, a copper alloy earring with a drop-shaped green glass bead (Figure 3), and some handmade, wheel-thrown ceramics decorated with horizontal notches and sharp wavelets. This archaeological information suggests that the deposition of the above-mentioned sequence occurred during the midto-latter part of the 14th century AD.

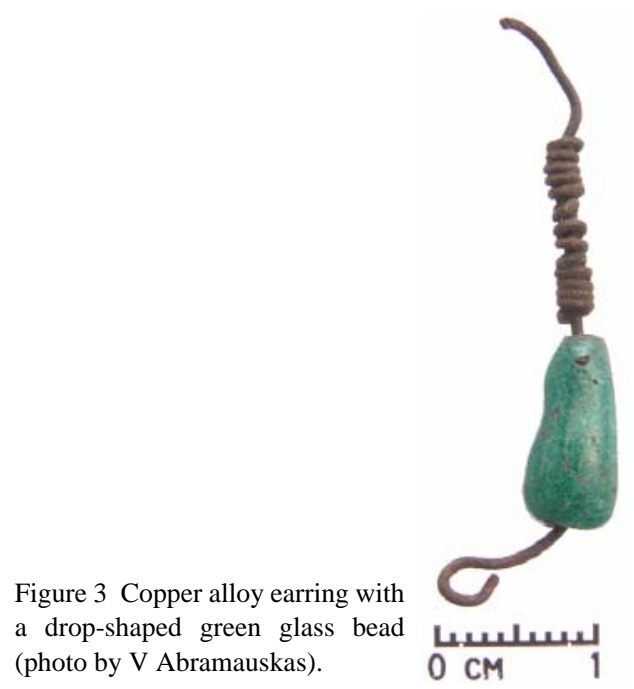

These archaeological finds also indicate the presence of intensive human activity in the area during the end of the 14th century AD. The interval of the cultural layer at about 88.95-89.70 m asl (sublayer 3) included a corner of a wooden building in the northwestern part of the site, a pole construction (most probably the gate) adjacent to that building, and a fence of upright planks. Outside the 
fence, a stove with a wicker frame of $1.5 \mathrm{~m}$ in diameter was discovered. Also discovered were a number of artifacts, including a King Charles' I (AD 1346-1378) Czech groat, a Grand Duke Vytautas' Lithuanian denarius (AD 1392-1393) (Figure 4), a fabric seal from western Europe, and a few socketed crossbow arrow tips. The chronological attribution of the above-mentioned interval was based upon these finds.

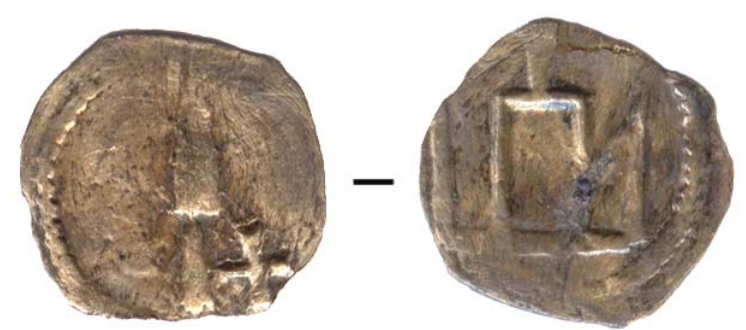

Figure 4 Grand Duke Vytautas’ Lithuanian denarius (silver coin, diameter 13-15 mm) (AD 1392-1393) (photo courtesy E Remecas).

The most abundant set of wooden constructions and findings was discovered in the interval of the cultural layer situated at 89.50-90.25 m asl (sublayers 1-3). In the northwestern part of the site, a timbered dwelling was excavated, while in the southeastern part of the site, excavations revealed a trapezium-shaped construction (about $2.5 \times 3 \mathrm{~m}$ ) that may have functioned as an outhouse or an annex. Throughout the site, the space between the buildings was covered with 2 or 3 levels of wooden flooring. The artifacts found in this layer include King Charles' I (AD 1346-1378) and King Wenceslas' IV (AD 1378-1419) Czech groats and Grand Duke Vytautas' Lithuanian coins, one dated at AD 1392-1393 and the other at AD 1410-1430, as well as a crossbow and bow arrowheads, a part of brigandine armor, and some fragments of polished pottery. Based on these findings, the formation of this layer was dated at the late 14th century to mid-15th century AD.

Excavated in the upper part (90.10-91.05 m asl, sublayers 1-2) of the investigated, organically enriched sediment sequence were the remains of several timbered dwellings. In one, the remains of a stove foundation, on which there was a layer of overheated clay with jug-shaped stove tiles, were found. Also discovered were 15th century Czech groats, a Grand Duke of Lithuania Casimir IV Jagiellon's coin (AD 1440-1492), and a few fragments of glass chalices dating back to the beginning of the 16th century $\mathrm{AD}$, all of which date the deposition of this sequence at the late 15th to early 16th century AD (Figure 2).

\section{Results of ${ }^{14} \mathrm{C}$ Dating}

${ }^{14} \mathrm{C}$ dating performed on 16 samples more or less evenly spaced along the sequence (Table 2) indicates that the investigated bed probably developed in 2 stages. The underlying terrigenous strata (sublayer 8, Table 1), which was dated to about cal AD 430-620, sample 16 (Table 2), could possibly be attributed to the first stage of the sedimentation. After a remarkable period of sedimentation hiatus, suggested in the chronological information, the deposition of the cultural layer or the second stage of the sedimentation in the territory began. The bottom part of the lowest cultural bed (sublayer 7, Table 1) was dated to about cal AD 1260-1390, sample 14, or cal AD 1220-1390, sample 15 (Table 2). The ${ }^{14} \mathrm{C}$ date representing the transition between sublayers 4 and 5 (cal AD 1300-1430, sample 12), the $2{ }^{14} \mathrm{C}$ dates of the lower part of sublayer 3 (cal AD 1280-1420, sample 10, and cal AD 1300-1440, sample 11), and the ${ }^{14} \mathrm{C}$ date of the middle part of sublayer 3 (cal AD 1295-1395, sample 8) confirm that the investigated material originated mainly from the 14th century AD. Only 
$1{ }^{14} \mathrm{C}$ date of sublayer 6 (cal AD 260-530, sample 13, Table 2) should be rejected due to a dating reversal, which may have resulted from the moving or reworking of the sediments by intensive human interference, perhaps by the digging of trenches and mounds of walls for wetland amelioration and dwelling construction. The ${ }^{14} \mathrm{C}$ dating also shows that the formation of the upper part of sublayer 3 continued during the 14th-15th centuries AD (cal AD 1310-1460, sample 5, cal AD 1300-1450, sample 6; cal AD 1300-1460, sample 7) and ended in the 16th century (cal AD 14301630, sample 2).

Table $2{ }^{14} \mathrm{C}$ data on sampled material.

\begin{tabular}{rclllcl}
\hline $\mathrm{Nr}$ & $\begin{array}{l}\text { Depth } \\
(\mathrm{cm})\end{array}$ & $\begin{array}{l}\text { Dated } \\
\text { material }\end{array}$ & Lab nr & $\begin{array}{l}\text { Produced } \\
\text { benzene }(\mathrm{g})\end{array}$ & $\begin{array}{l}\text { Uncalibrated } \\
{ }^{14} \mathrm{C} \mathrm{BP}\end{array}$ & $\begin{array}{l}\text { Calibrated, AD } \\
(1 \sigma, 68 \%)\end{array}$ \\
\hline 1 & $18-20$ & Sediment & Ki-12486 & $\mathrm{n} / \mathrm{d}$ & $860 \pm 50$ & AD 1150-1260 \\
2 & $15-20$ & Wood & Vs-1627 & 0.53 & $710 \pm 120$ & AD 1210-1400 \\
3 & $45-50$ & Wood & Vs-1624 & 2.1 & $410 \pm 70$ & AD 1430-1630 \\
4 & $70-75$ & Wood & Vs-1626 & 1.9 & $400 \pm 70$ & AD 1430-1630 \\
5 & $105-110$ & Wood & Vs-1604 & 0.81 & $500 \pm 70$ & AD 1310-1460 \\
6 & $105-110$ & Sediment & Vs-1607 & 1.2 & $520 \pm 80$ & AD 1300-1450 \\
7 & $120-125$ & Wood & Vs-1601 & 0.4 & $520 \pm 90$ & AD 1300-1460 \\
8 & $150-155$ & Wood & Vs-1606 & 2.3 & $620 \pm 50$ & AD 1295-1395 \\
9 & $188-190$ & Sediment & Ki-12484 & n/d & $870 \pm 70$ & AD 1040-1240 \\
10 & $208-213$ & Wood & Vs-1603 & 0.28 & $620 \pm 110$ & AD 1280-1420 \\
11 & $215-220$ & Wood & Vs-1625 & 0.9 & $560 \pm 90$ & AD 1300-1440 \\
12 & $240-245$ & Sediment & Vs-1609 & 1.3 & $560 \pm 80$ & AD 1300-1430 \\
13 & $278-280$ & Sediment & Ki-12485 & n/d & $1650 \pm 50$ & AD 260-530 \\
14 & $300-305$ & Wood & Vs-1602 & 1.9 & $690 \pm 50$ & AD 1260-1390 \\
15 & $300-305$ & Sediment & Vs-1605 & 1.33 & $710 \pm 70$ & AD 1220-1390 \\
16 & $312-314$ & Sediment & Ki-12483 & n/d & $1520 \pm 100$ & AD 430-620 \\
\hline
\end{tabular}

For some samples (depth intervals of 45-50, 70-75, 188-190, and 278-280 cm), the calibrated ages have significantly larger error terms than measurement errors because of plateaus and wiggles on the calibration curve (Ammann and Lotter 1989; Stuiver et al. 1998). In addition, several dates (depth intervals of 15-20, 208-213, and 215-220 cm) have no significant plateaus and wiggles on the calibration curve. However, in the case of some samples, due to the large measurement errors (small benzene amount) and wiggles on the calibration curve, the bimodal calibrated age range is characteristic. For some investigated intervals, double sampling of sediment and an associated wood piece was possible (intervals 105-110 and 300-305 cm). For those intervals, both materials were dated approximately to the same age. This correlation of dates suggests that for the major part of the studied sequence, the number of errors that can be attributed to "inbuilt" or "pre-sample" age (Bowman 1995 ) is low. The calibrated ${ }^{14} \mathrm{C}$ age of wood and sediment grouped according to sequence depth is presented in Figure 5.

Two ${ }^{14} \mathrm{C}$ dates on the top part of the sequence, sediment (cal AD 1150-1260, sample 1) and wood (cal AD 1210-1400, sample 2), produced age offsets and were too old compared to the prevailing dates of the 14th century AD. The reason for these outliers may be attributed to the mobility and incorporation of material from an earlier phase of activity in a later archaeological deposit (disturbed and redeposited material). 


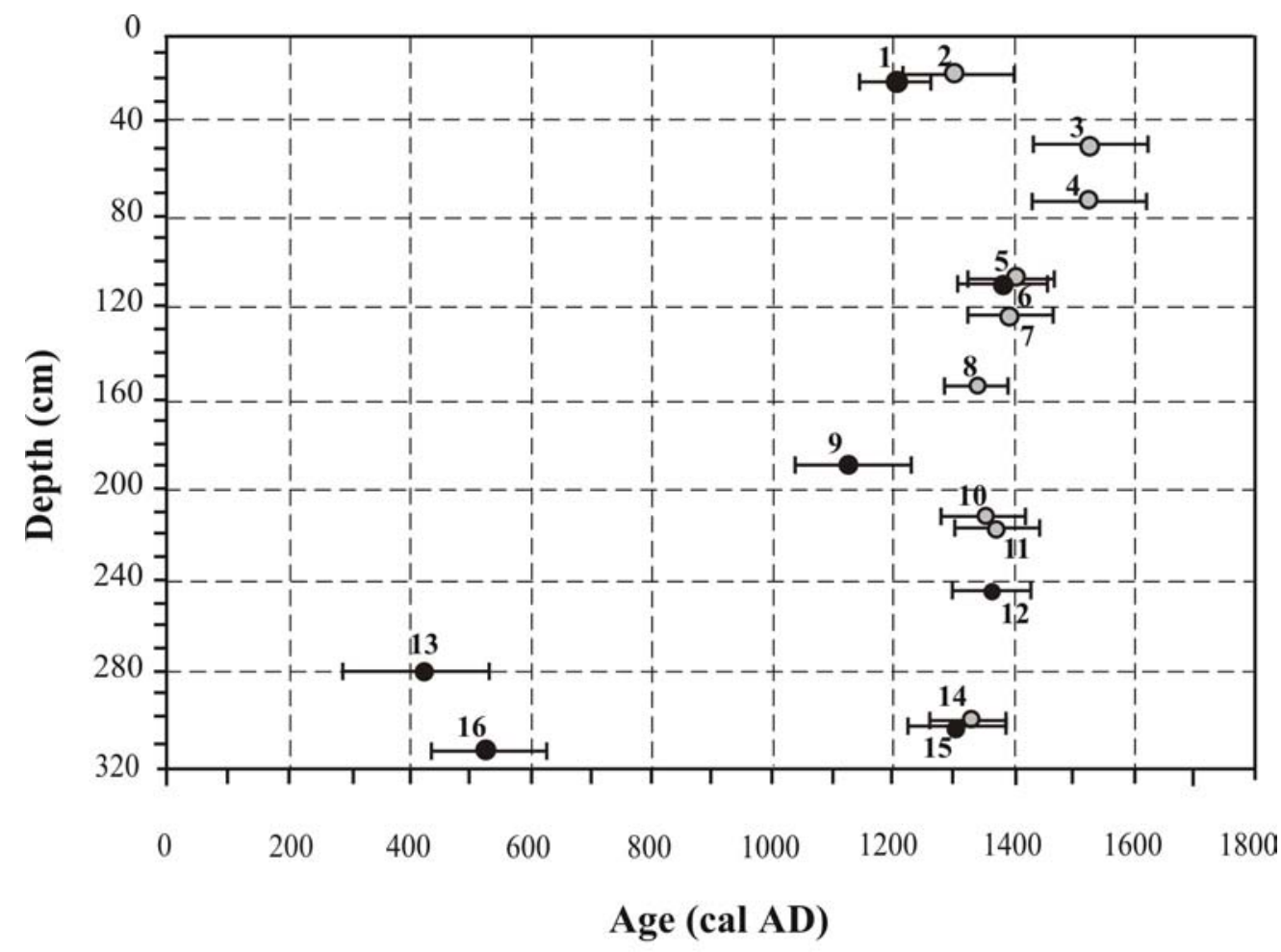

O Dated wood

Dated sediment

Figure 5 Calibrated ${ }^{14} \mathrm{C}$ age with $1-\sigma$ ranges of sampled material grouped according to depth. Numbers next to data points denote the number of samples (as in Table 2).

\section{Archaeobotanical Investigations}

The pollen spectra (K-1, Figure 6) suggest that woodland, mainly Pinus with the presence of Betula, Picea, Ulmus, and Quercus, flourished in the area during the 6th century AD. However, a high representation of weeds; several species of woodland glades; cereals, e.g. Cannabis sativa (the seventh sample, Figure 7); and ruderals, e.g. Solanum nigrum and Chenopodium album, indicates that intensive human activity occurred in the territory. Consequently, open land was also common in the area. The decline of woodland cover recorded in the pollen diagram (K-2, Figure 6) coincides with archaeological evidence and ${ }^{14} \mathrm{C}$ dating, all of which place the formation of the cultural layer at the late 13th to early 14th centuries AD. The high number of recorded apophytes points towards the existence of pastures and grasslands, while a continuously high proportion of undifferentiated Cerealia and the presence of Linum usitatissimum together with Fagopyrum pollen indicates that intensive agriculture occurred in the area (K-2, Figure 6). Also present in the sediments were single glumes of Panicum miliaceum and charred caryopses of Secale cereale, as well as seeds of Chenopodium album and Solanum nigrum (the sixth sample, Figure 7).

While evidence of some development of the vegetation cover suggests that the open land was briefly reoccupied by woods around the middle of the 14th century AD (K-3, Figure 6), the high proportion of apophytes and anthropochores pollen points to the continuous existence of agricultural fields and pastures in the area. Approaching the end of the 14th century AD, this regression was followed by a 


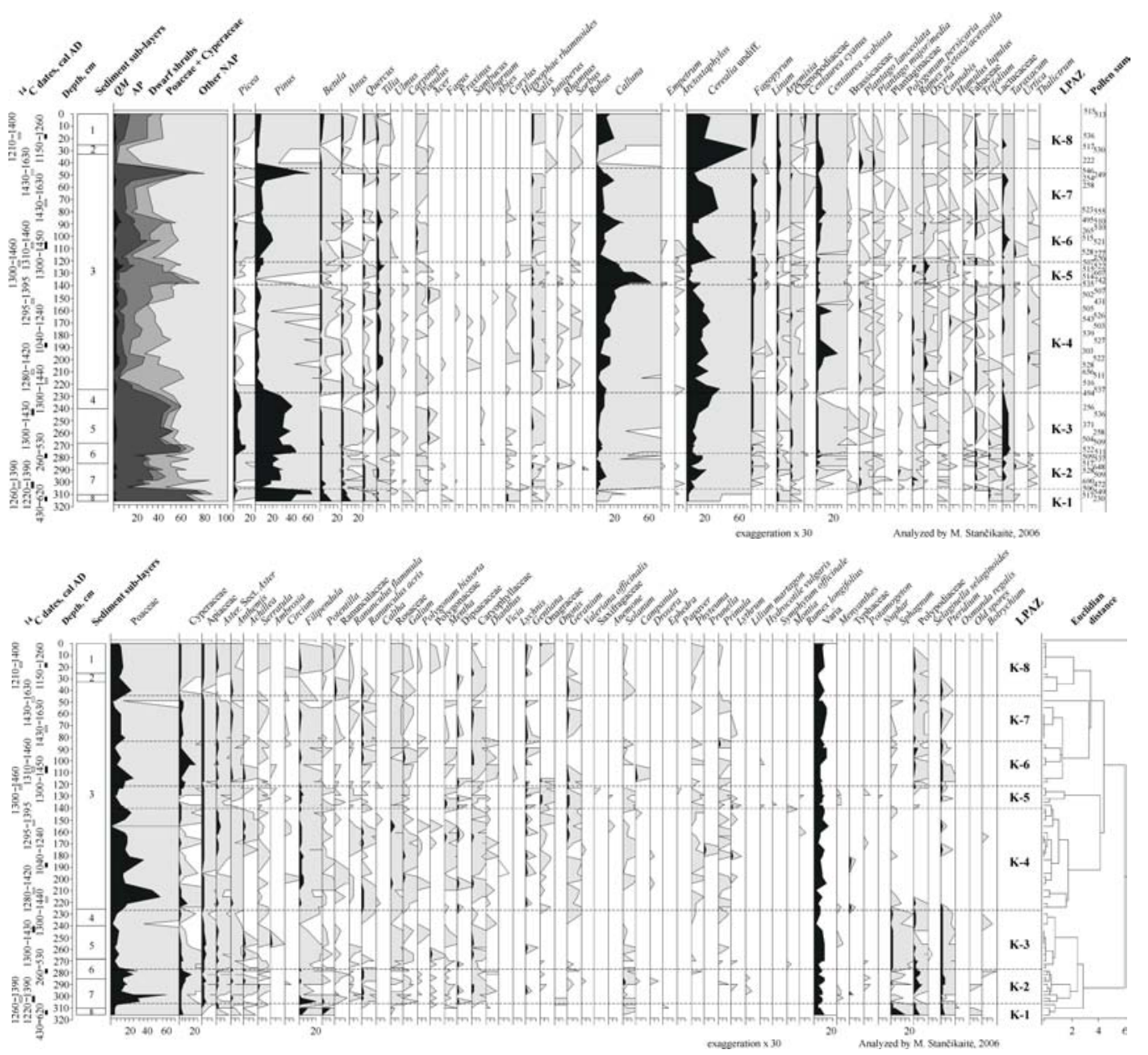

Figure 6 The percentage pollen diagram. See Table 1 for a detailed description of sediment sublayers.

marked expansion of the underwood vegetation, including agricultural fields and grasslands (K-4, Figure 6). In particular, it was shown that the intensity of permanent agriculture was very high. Cerealia undifferentiated and Fagopyrum pollen are recorded continuously in the sample, and plant macroremains typical for millet and gardens together with that common in cereal and flax fields are abundant (fourth and fifth samples, Figure 7).

Although the AP/NAP ratio shows some temporal expansion of woodland, a very high frequency of ruderals and crop plants pollen points to the peak of human activity in the area that started during the last decades of the 14th century AD and continued until the first half of the 16th century (K-5 to K8, Figures 6a,b). Fagopyrum esculentum together with Panicum miliaceum and numerous remains of weeds common in cereal and flax fields (Fallopia convolvulus and Galeopsis tetrahit type) and gardens or millet fields (Echinochloa crus-galli and Setaria pumila) macrofossils confirm the existence of local agriculture (Figure 7). 


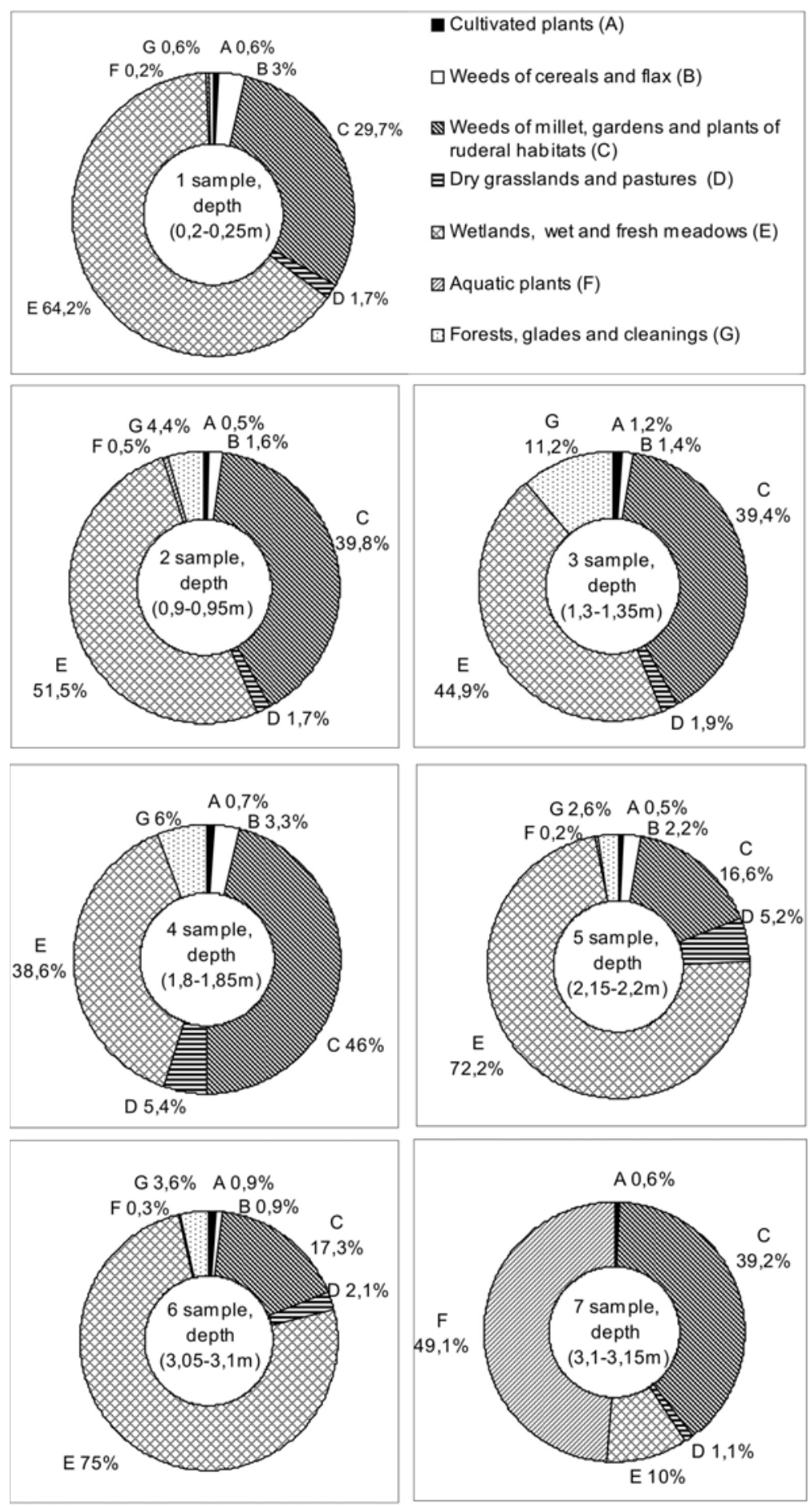

Figure 7 Representation of ecosociological groups based on the percentage of diaspores in the appropriate macroremains samples. 


\section{DISCUSSION}

The study carried out at the Vilnius Lower Castle has provided us with new information on the chronological framework of this archaeological site. It has also shed light on the main features of the how the landscape evolved as well as the character of the human activity in the area.

It is most likely that the investigated sediment sequence began to form at about cal AD 430-620 (Figure 5). Because only a single date represents the lowermost part of the sequence and no archaeological finds representing this bed have been discovered in the investigated plot, it has not been possible to determine conclusively the chronological attribution of this sublayer. Nevertheless, the above-mentioned chronology of the investigated cultural layer is supported by the results of previous archaeological investigations of the territory in which the remains of the oldest permanent settlement discovered were dated back to the 6th century AD (Tautavičius and Urbanavičius 1995). Cereals and ruderals typical of millet fields and gardens were discovered in newly collected archaeobotanical material, which proves the existence of forest-free plots, most probably agriculture fields, in the surrounding territories during the 6th century AD.

Although a $1-\sigma$ range of ${ }^{14} \mathrm{C}$ dates is wide and thus insufficient for detailed chronological attribution of the investigated strata, it is nonetheless possible to conclude from the available information that the deposition of the cultural layer started in the second half of the 13th century AD. This conclusion correlates well with the dendrochronological data, which suggests that the oldest buildings discovered in the investigated plot were constructed in approximately AD 1287-1288 (Pukienè 2007). Furthermore, historical documents and previously collected archaeological data date the earliest phase of the construction of the Vilnius Lower Castle back to the 13th to beginning of the 14th century AD (Kitkauskas 2001). New archaeological data from the investigated plot, however, places this period at a somewhat later age. Jewelry and ceramics discovered in the lower part of the cultural layer (87.20-88.95 $\mathrm{m}$ asl) indicate that the deposition of these beds occurred during the middle to later half of the 14th century AD (Figure 2). This date, though, is somewhat inconclusive due to the infrequent occurrence of archaeological finds in the relatively small excavated plot. Nevertheless, the new chronological data, including the results of dendrochronological and ${ }^{14} \mathrm{C}$ dating, has extended our knowledge of the earliest stages of intensive human activity in the investigated area.

Moreover, the archaeobotanical data from the mentioned sublayer suggests that human interference increased during this period, as did the expansion of open meadows and arable fields. Panicum miliaceum and Secale cereale macroremains and pollen of Cerealia (Cannabis sativa, Linum usitatissimum, and Fagopyrum) point to intensive agricultural activity (Figures 6a,b and 7), and the storage of surplus plants and grain is suggested by an absence of hearths in some of the excavated buildings in the area. From this, it can be assumed that at least a part of the discovered pollen and plant macroremains were transported to the Lower Castle together with the crop (Stančikaite et al. 2008).

The findings also show that ongoing cultural activity continued in the area throughout different periods of the 14th century. The age of discovered artifacts, such as a King Charles I (1346-1378) Czech groat and a Grand Duke Vytautas Lithuanian denarius (1392-1393) (87.20-89.70 m asl), set the chronological attribution of the excavated layers in good correlation with the ${ }^{14} \mathrm{C}$ data. Any differences that appear between the established chronological framework and scattered dating may be attributed to the remobilization and reworking of the cultural layer as a result of intensive human interference. Archaeological and historical records document considerable increases in the human population of Vilnius during the second half of the 14th century (Urbanavičius 2003), a period of significant changes in the history of the Lithuanian state and of Vilnius. In 1387, after the Christianization of Lithuania, Vilnius was granted Magdeburg Rights, and new parishes inhabited by strong 
Russian and German communities began to grow (Bumblauskas 2005). Corresponding with these social transformations and increased human activity was a rise in human pressure on the local environment. Where the intensity of the agriculture increased, an open landscape simultaneously predominated in the region, as is shown by the archaeobotanical records.

A new archaeological record indicates that the formation of the upper part of the cultural layer continued during the late 14th to early 15th century (89.70-90.25 m asl, Figure 2). Archaeological and historical data show that the beginning of the 15th century was a period of progressive economic and cultural development in Lithuania and in Vilnius (Urbanavičius 2003). Especially rich archaeological material containing numerous luxury goods was discovered in the cultural layer of the Vilnius Lower Castle (Steponavičienè 2007). The presence, for instance, of King Charles I (1346-1378) and King Vaclav IV (1378-1419) Czech groats and Grand Duke Vytautas Lithuanian coins dated to 1392-1393 and 1410-1430, respectively, form the basis of the chronological attribution of the recently excavated deposits. The chronology spanning the last decades of the 14th century and the first half of the 16th century are basically confirmed by the results of ${ }^{14} \mathrm{C}$ dating. However, the $1-\sigma$ range of ${ }^{14} \mathrm{C}$ dates is wide and can even extend into the 17 th century $\mathrm{AD}$. These discrepancies between the ${ }^{14} \mathrm{C}$-based age and that validated by the archaeological data may be attributed to different causes. To us, this is most likely due to the increasing level of sediment remobilization, which is especially important for ${ }^{14} \mathrm{C}$ dating. Supporting this assumption are the documented, repeated constructions of buildings on the site and the transformation of the territory during the latter ages (Urbanavičius 2003), although, for the construction of a more detailed chronological scheme based on ${ }^{14} \mathrm{C}$ investigations, additional data is required.

In the uppermost part of the profile, a remarkable difference between the ${ }^{14} \mathrm{C}$ and archaeological dating was recorded. The archaeological record indicates that the deposition of the cultural strata (90.25-91.05 $\mathrm{m}$ asl) occurred during the later 15th to early 16th century (Figure 2), as determined by the presence of 15th century Czech groats, a Grand Duke of Lithuania Kazimieras IV Jagiellon coin (1440-1492), and a few fragments of glass chalices that date back to the beginning of the 16th century. The ${ }^{14} \mathrm{C}$ dates, however, suggest that the layer is much older (Table 2). The intensive occupation of the site and the reconstructions of the territory recorded in the historical data led to the continuous introduction of outside sediments and wood pieces to the territory. Consequently, the occurrence of older material cannot be excluded. As such, because the development of the sequence and information collected from the surrounding areas suggests that the layers $(90.10-91.05 \mathrm{~m}$ asl) represent a much later period than that indicated by ${ }^{14} \mathrm{C}$ dating, the chronological attribution of this part of the profile should clearly be based on the archaeological material and the 2 uppermost ${ }^{14} \mathrm{C}$ dates must be rejected.

\section{CONCLUSIONS}

The interdisciplinary research conducted in the territory of the Vilnius Lower Castle in eastern Lithuania has formed a valuable basis for the chronological identification of the cultural strata. It has also enabled a wide-ranging discussion on the unresolved questions regarding the reconstruction of the surrounding landscape and the character of human activity in the area.

The ${ }^{14} \mathrm{C}$ results and archaeological context correlate, in principal, with the established local historical record. Namely, based on ${ }^{14} \mathrm{C}$ and dendrochronological data (new data by R Pukiené), it has been confirmed that the expansion of cultural activity in the investigated area began during the latter half of the 13th century AD. While this conclusion has not yet been supported by the archaeological record from the investigated plot, it has been shown that the second half of the 13th to the onset of 14th century AD coincided with a period of increasing human activity, including the development 
of agriculture and the artificial opening of the vegetation cover. Because of the sufficient correlation between ${ }^{14} \mathrm{C}$ and archaeological data, we were also able to confidently determine the chronology of the most intensive human interference in the area. This period began in the second half of the 14th century $\mathrm{AD}$ and continued throughout the first half of the 15th century AD.

As noted in some parts of the investigated profile, the discrepancies between the archaeological chronological attribution and the ${ }^{14} \mathrm{C}$ dates may be attributed both to artificial disturbances in the cultural layer deposition due to intense human activity and to the limitations of ${ }^{14} \mathrm{C}$ dating in a particular context, as the dating of sediment by conventional ${ }^{14} \mathrm{C}$ technique still remains problematic. To resolve this problem, it is recommended that samples be pretreated at the molecular level where specific organic compounds are isolated, although this would require an accelerator mass spectrometry (AMS) facility for small samples. Additionally, because this site is rich in well-preserved wooden artifacts, another potential method for building the chronology of this particular site is to combine conventional statistical ${ }^{14} \mathrm{C}$ dating with dendrochronological methods.

\section{ACKNOWLEDGMENTS}

The authors thank Dr Daiva Steponavičienė, a leader of the archaeological team, for the great help, discussions, and cooperation and to Vadim Skripkin from the Radiocarbon Laboratory in Kiev (Institute of Geochemistry of Environment, National Academy of Sciences of Ukraine) for ${ }^{14} \mathrm{C}$ measurement of the small samples. Dr Rimantas Petrošius and Gintautas Davainis are acknowledged for assistance in the laboratory with the ${ }^{14} \mathrm{C}$ assays. We are grateful to Prof M Latałowa (Laboratory of Palaeoecology and Archaeobotany, University of Gdańsk, Poland) for helping with the identification of the fruits and seeds, comments and suggestions on the material, and generous collaboration. We thank 2 anonymous reviewers for constructive remarks on the manuscript. Linguistic revision of the text was done by Chris Featherman. This study was funded by the Lithuanian State Science and Studies Foundation, as a part of the PALAEOCLIMATE project (C-07008).

\section{REFERENCES}

Ammann B, Lotter AF. 1989. Late-Glacial radiocarbonand palynostratigraphy on the Swiss Plateau. Boreas 18(2):109-26.

Arslanov KhA. 1985. Radiocarbon: Geochemistry and Geochronology. Leningrad. In Russian.

Behre KE, Jacomet S. 1991. The ecological interpretation of archaeobotanical data. In: van Zeist W, Wasylikowa K, Behre KE, editors. Progress in Old World Palaeoethnobotany. Rotterdam: Balkema. p 81-108.

Bowman S. 1995. Radiocarbon Dating. London: British Museum.

Bronk Ramsey C. 1995. Radiocarbon calibration and analysis of stratigraphy: the OxCal program. Radiocarbon 37(2):425-30.

Bronk Ramsey C. 2001. Development of the radiocarbon calibration program. Radiocarbon 43(2A):355-63.

Bumblauskas A. 2005. Senosios Lietuvos istorija 10091795 [History of Ancient Lithuania 1009-1795]. Vilnius: R. Paknio leidykla.

Butrimas A. 1992. Spigino Mezolito kapai (Mesolithic graves on Spiginas Island). Lietuvos archeologija 8:4 10. In Lithuanian.

Erdtman G. 1936. New methods in pollen analysis. Svensk Botanisk Tidskrift 30:154-64.
Gaigalas A. 1999. Geological foundation and geomorphological conditions of the Lower Castle of Vilnius. In: Urbanavičius V, editor. Vilniaus Žemutinès pilies rümai (1994-1995 metu tyrimai) Vilnius: Leidybos centras. p 320-1.

Grichiuk VP. 1940. Processing of deposits poor in the organic material for pollen analysis. In: Grichiuk VP. Problems of the Physical Geography. Moscow: Nauka. p 40-68. In Russian.

Grigas A. 1986. Lietuvos augalu vaisiai ir sėklos [Fruits and seeds of Lithuanian plants]. Vilnius: Mokslas.

Grimm EC. 1992. TILIA and TILIA-GRAPH: PC spreadsheet and graphics program. In: 8th International Palynological Congress. Program and $A b-$ stracts. Aix-en-Provence, France.

Gudzinskas Z. 1999. Lietuvos induočiai augalai [Vascular Plants of Lithuania]. Vilnius: Institute of Botany.

Guobytė R. 2002. Lithuanian surface: geology, geomorphology and deglaciation [abstract of PhD dissertation]. Vilnius. 31 p.

Gupta SH, Polach HA. 1985. Radiocarbon Practices at ANU, Handbook. Canberra: Australian National University.

Jacquat Ch. 1988. Hauterive-Champréveyres, 1. Les 
plantes de l'âge du Bronze. Catalogue des fruits et graines. Archéologie neuchâteloise 7. Saint-Blaise: Editions du Ruau.

Kitkauskas N. 1989. Vilniaus Pilys. Statyba ir architektüra [Vilnius Castle. Construction and Architecture]. Vilnius: Mokslas.

Kitkauskas N. 2001. Vilniaus piliu architektüros raida. Lietuvos piliu archeologija. [Development of the architecture of Vilnius Castles. Archaeology of Lithuanian Castles]. Vilnius: Klaipėda. p 153-72.

Kovaliukh NN, Skripkin VV. 1994. An universal technology for oxidation of carbon-containing materials for radiocarbon dating. In: Abstracts and Papers of Conference on Geochronology and Dendrochronology of Old Town's and Radiocarbon Dating of Archaeological Findings. Vilnius, Lithuania, 31 October-4 November. Vilnius: Vilnius University Press. p 3742.

Kuncevičius A. 2005. Lietuvos viduramžiu archeologija [Lithuanian Medieval Archaeology]. Vilnius: Versus aureus.

Latałowa M. 1999. Palaeoecological reconstruction of the environmental conditions and economy in the early medieval Wolin-against a background of the Holocene history of the landscape. Acta Palaeobotanica 39(2):183-271.

Latałowa M, Badura M, Jarosińska J. 2003. Archaeobotanical samples from non-specific urban contexts as a tool for reconstructing environmental conditions (examples from Elblag and Kołobrzeg, northern Poland). Vegetation History Archaeobotany 12:93-104.

Moore PD, Webb JA, Collinson ME. 1991. Pollen Analysis. Oxford: Blackwell.

Pazdur MF, Awsiuk R, Goslar T, Pazdur A. 1994. Chronologia radiowęglowa początków osadnictwa w Wolinie i zeglugi u ujścia Odry [Radiocarbon chronology of the Wolin settlement and navigation at the mouth of Odra River]. Geochronometria 9:127-95. In Polish.

Pukienè R, Ožalas E. 2007. Medieval oak chronology from the Vilnius Lower Castle. Dendrochronologia 24:137-43.

Pukienè R. 2007. Mediniai XIV a. kelio grindiniai Vilniaus Žemutinėje Pilyje. Dendrochronologinè analizè ir datavimas [Wooden road pavements of the 14th century A.D. in the Vilnius Lower Castle. Den- drochronological analysis and dating]. In: Glemža E, editor. Vilniaus Žemutine Pilis XIV a.-XIX a. pradžioje. Vilnius: Lietuvos Pilys. p 182-94.

Reimer PJ, Baillie MGL, Bard E, Bayliss A, Beck JW, Bertrand CJH, Blackwell PG, Buck CE, Burr GS, Cutler KB, Damon PE, Edwards RL, Fairbanks RG, Friedrich M, Guilderson TP, Hogg AG, Hughen KA, Kromer B, McCormac G, Manning S, Bronk Ramsey C, Reimer RW, Remmele S, Southon JR, Stuiver M, Talamo S, Taylor FW, van der Plicht J, Weyhenmeyer CE. 2004. IntCal04 terrestrial radiocarbon age calibration, 0-26 cal kyr BP. Radiocarbon 46(3):102958.

Rimantienė R. 2005. Die Steinzeit Fischer an der Ostseelagune in Litauen. Vilnius: Lietuvos Nacionalinis Muziejus. In German with English summary.

Stančikaitė M, Kisielienė D, Mažeika J, Blaževičius P. 2008. Environmental conditions and human interference during the 6th and 13th-15th centuries A.D. at Vilnius Lower Castle, east Lithuania. Vegetation History and Archaeobotany 17(1):239-50.

Steponavičienė D. 2007. The Luxury of Vilnius Court of Lithuanian Grand Duke in 13th-Early 16th Century. Vilnius: Versus Aureus.

Stuiver M, Reimer PJ, Braziunas TF. 1998. High-precision radiocarbon age calibration for terrestrial and marine samples. Radiocarbon 40(3):1127-51.

Tautavičius A, Urbanavičius V. 1995. Archeologiniai tyrimai [Archeological investigations]. In: Tautavičius A, editor. Vilniaus Žemutinès pilies rümai (1990-1993 metu tyrimai). Vilnius: Leidybos centras. p 112-32.

Urbanavičius V. 2003. Vilniaus Žemutinès pilies rümai, 1996-1998 metu tyrimai [The Lower Castle of the Vilnius Palace, Investigations of 1996-1998]. Vilnius: Sapnų sala.

Veski S, Heinsalu A, Klassen V, Kriiska A, Lõugas L, Poska A, Saluäär U. 2005. Early Holocene coastal settlements and palaeoenvironment on the shore of the Baltic Sea at Pärnu, southwestern Estonia. Quaternary International 130(1):75-85.

Zagorska I. 2006. Radiocarbon chronology of the Zvejnieki burials. In: Larsson L, Zagorska I, editors. Back to the origin. New research in the MesolithicNeolithic Zvejnieki cemetery and environment, northern Latvia. Acta Archaeologica Lundensia 8(52):91115. 